\title{
BODY COMPOSITION OF FEMALE SENIOR INHABITANTS OF BIAŁA PODLASKA VS THEIR PHYSICAL ACTIVITY
}

\author{
AGNIESZKA WASILUK, JERZY SACZUK \\ The Josef Pilsudski University of Physical Education in Warsaw, \\ Faculty of Physical Education and Sport in Biala Podlaska, \\ Department of Anthropology and Anthropomotorics
}

\author{
Mailing address: Agnieszka Wasiluk, Faculty of Physical Education and Sport, \\ Department of Anthropology and Anthropomotorics, 2 Akademicka Street, 21-500 Biala Podlaska, \\ tel.: +48 83 3428741, fax: +48 83 3428800, e-mail: agnieszka.wasiluk@awf-bp.edu.pl
}

\begin{abstract}
Introduction. The aim of this study was to analyze body composition of female inhabitants of Biała Podlaska aged 60 years and older and characterized by different levels of physical activity. Material and methods. The study material were results from a survey conducted with 180 female inhabitants of Biała Podlaska aged 60 years and older ( $\widetilde{\mathrm{x}} 65.30 \pm 4.68$ ). The women were analyzed for body height, body mass, BMI and body composition. Their physical activity was determined using the IPAQ questionnaire and according to results achieved the women were classified into two groups: low physical activity $(\mathrm{n}=132)$, and moderate and high physical activity $(\mathrm{n}=48)$. The average frequency, duration and weekly energy expenditure of physical activities undertaken by the respondents were estimated in both groups. In addition, a social enquiry was conducted that enabled gathering information on the level of education, marital status and family status of the women. Results achieved were elaborated statistically. Results. The marital status $\left(x^{2}=11.001, p<0.05\right)$ and family status $\left(x^{2}=4.113, p<0.05\right)$ of the female senior inhabitants of Biała Podlaska were modifying their physical activity to a greater extent that the educational status did $\left(x^{2}=30.360, p>0.05\right)$. In addition, significant correlations were observed between absolute values of tissue components of the body and physical activity of the senior women. The average total energy expenditure in the group with a low physical activity accounted for 236.5 MET, whereas in the group with moderate and high physical activity - for 2255.3 MET. Conclusions. The study demonstrated that not only time devoted to physical activity but also its intensity affected the levels of tissue components. Results achieved in the survey indicate the necessity of continuing studies to examine correlations between body composition and physical activity of older population.
\end{abstract}

Key words: women, physical activity, BMI, body composition

\section{Introduction}

The World Health Organization adopts the $60^{\text {th }}$ year of life as the beginning of old age, however it distinguishes its three main stages, i.e. advanced aged (the so-called early old age) spanning from 60 to 75 years of age; followed by the period of 75 to 90 years acknowledged as the senile age (the so-called late old age); and finally the period over 90 years noted as the ripe old age also referred to as longevity [1]. The process of ageing in-volves a number of changes and impairments in the functioning of tissues and organs [2]. At the advanced age skeletal muscles lose their mass and become less resilient and efficient. This is due, among other things, to changes in the nervous system and the muscles themselves, and may result from a lower physical activity of older persons. Apart from a decreasing number of motor neurons, the condition of muscles may be influenced by damages generated during muscle contractions and oxidative stress, changes in cells enveloping the muscles, displacement of the muscle tissue by connective and fatty tissue, suppressed synthesis of muscle proteins, increased concentration of proinflammatory cytokines, and diminished muscle perfusion. Losses in muscle mass and strength are undoubtedly influenced by age-dependent reduction in the production of testosterone, estrogens and growth-hormone and by an increased serum level of insulin-like growth factor-1 (IGF-1) [3]. In the described pe- riod of ontogenesis, changes are also observed in the structure and resistance of the osseous tissue, that are characterized by progressing losses in bone mass, deterioration of the spatial structure of bones and increased susceptibility to fractures [4]. The process of ageing is determined genetically and modified by environmental factors and lifestyle [5]. In turn, a person's health and functioning in the environment are determined by the physical activity, which prolongs physical fitness and functional independence of an individual. A cross-sectional study demonstrates that the maximum aerobic capacity of the body $\left(\mathrm{VO}_{2 \max }\right)$ decreases with age [6]. Self-dependent functioning requires some minimum of the aerobic yield of the body which is stipulated at $18 \mathrm{~mL} / \mathrm{kg} / \mathrm{min}$ in men and at $15 \mathrm{~mL} / \mathrm{kg} / \mathrm{min}$ in women [6]. Physical training increases physical fitness and delays $\mathrm{VO}_{2 \max }$ decline in physically-active persons compared to those leading a sedentary lifestyle. Even an insignificant increase in $\mathrm{VO}_{2 \max }$ may extend the period of independence of the third persons. In addition, physically-active persons are less exposed to the risk of development of many chronic diseases including cardiovascular diseases, cerebral stroke, hypertension, type 2 diabetes, obesity or neoplasmic diseases [7].

The complexity of body response to physical exertion causes that it is very difficult to determine the optimal intensity and duration of a health-supporting training. Both the excessive and insufficient physical activity may have adverse effects [8]. 
Hence, of crucial significance is the analysis of correlations between the level of physical activity and physical condition of the body.

The aim of this study was to analyze body composition of female inhabitants of Biała Podlaska aged 60 years and older and characterized by different levels of physical activity.

\section{Material and methods}

The study material were results from a survey conducted with 180 female inhabitants of Biała Podlaska aged 60 years and older ( $\widetilde{x} 65.30 \pm 4.68$ ). The surveyed population (sample) was selected using administrative division of the city considering all housing estates. The criteria excluding the women from the study included: disorders of carbohydrate metabolism, arterial hypertension, neoplasmic diseases and long-term administration of body mass-determining drugs (diuretics, corticosteroids, psychotropic drugs). The above criteria resulted from the procedure of electric resistance measurement in the body of the surveyed women using a body composition analyzer. Examinations were conducted in morning hours. The women were on an empty stomach, in light clothing uncovering forearms and feet, and shoeless. One kilogram was deduced from their body mass as the weight of clothing.

Body height measurements were made using an anthropometer exact to $0.1 \mathrm{~cm}$. Body mass was measured with a TP-150 WTL B electronic scales exact to $0.1 \mathrm{~kg}$. Results obtained were used to calculate Body Mass Index (BMI) defined as the ratio of body mass to the square of body height $\left(\mathrm{kg} / \mathrm{m}^{2}\right)$ [9].

Tissue composition of the body was estimated with the method of bioelectric impedance using an Akern BIA body composition analyzer [10]. Particular body components were computed with BODYSTAT 1.3 software.

The physical activity of the senior female respondents was evaluated with the use of an individual interview using a short version of the IPAQ questionnaire [11]. Energy expenditure was expressed in MET (min/week). The respondents were asked about their physical activity linked with everyday life, work and leisure time undertaken within the last week. Based on the results achieved, the respondents were divided into two groups:

- women with low physical activity who declared no physical activity or whose activity did not involve the energy expenditure of $600 \mathrm{MET}$ (lACT);

- women with moderate and high physical activity, the energy expenditure of which reached min. 600 MET (hACT).

The average frequency, duration and weekly energy expenditure of physical exertions undertaken by the respondents were estimated in the above groups [12].

In addition, a social enquiry was conducted that enabled gathering information on the level of education, marital status and family status of the women. The following categories were adopted in analyses:

- education: primary, occupational, secondary, higher;

- marital status: maid, married, widow, single (divorced, in separation);

- family status: living alone, living with the family (household with adults), living with the juveniles (household with the juveniles).

The survey was conducted in compliance with the Helsinki Declaration and was approved by the Senate Ethical Commission acting at the Academy of Physical Education in Warsaw.

Results achieved were elaborated statistically. The following descriptive statistics were used for the characteristics of variables: arithmetic mean ( $\widetilde{\mathrm{x}})$ and standard deviation (SD). Differences in values of somatic traits, BMI, body composition and physical exertions of the women with different levels of physical activity were evaluated using the Student's t-test for independent data. In turn, the $\boldsymbol{X}^{2}$ test was applied to evaluate correlations between non-parametric variables. Differences were found significant at $\mathrm{p} \leq 0.05$.

\section{Results}

Table 1 presents the general characteristics of the surveyed senior women. Their mean body height was at $159.4 \mathrm{~cm}$, whereas body mass was at $73 \mathrm{~kg}$. The correctness of mass-toheight proportion is indicated by BMI value which in the analyzed population pointed to incorrect mass-to-height proportion in $78.83 \%$ of the women, including overweight in $39.44 \%$ and obesity in $38.89 \%$ of the surveyed female seniors. In addition, alarmingly high was the percentage of fatty tissue in the total body mass of the women (40.5\%). The fatty tissue content of the body was exceeded compared to WHO standards in $88.88 \%$ of the women. In turn, lean body mass constituted $59.6 \%$ whereas water content reached $47.3 \%$ of the total body mass.

Table 1. Statistical characteristics of somatic traits in the surveyed women

\begin{tabular}{|l|c|c|}
\hline & $\mathrm{x}$ & SD \\
\hline Body height [cm] & 159.4 & 6.0 \\
\hline Body mass $[\mathrm{kg}]$ & 73.0 & 12.1 \\
\hline BMI $\left[\mathrm{kg} / \mathrm{m}^{2}\right]$ & 28.3 & 4.5 \\
\hline Fatty tissue [kg] & 30.2 & 9.4 \\
\hline Fatty tissue [\%] & 40.5 & 7.0 \\
\hline Lean body mass [kg] & 42.8 & 4.4 \\
\hline Lean body mass [\%] & 59.6 & 6.9 \\
\hline Total water [L] & 34.0 & 3.4 \\
\hline Total water [\%] & 47.3 & 5.1 \\
\hline
\end{tabular}

The educational status of the women had no significant effect on differences in the level of their physical activity $\left(X^{2}=30.360 ; p>0.05\right)$. In both groups of physical activity, the highest percentage of the seniors had secondary education (72.81\% lACT, $54.17 \%$ hACT). In the group with low physical activity, $10.68 \%$ of the women completed occupational school, whereas $8.74 \%$ of the women finished their education on primary school. The lowest percentage of women had higher education $(7.77 \%)$. In turn, amongst the senior female inhabitants of Biała Podlaska with moderate or high physical activity, $37.51 \%$ had higher education. The percentage of women with primary and occupational education was low and reached $4.15 \%$ in both categories (Tab. 2). 
Table 2. Social determinants of physical activity of the surveyed women

\begin{tabular}{|c|c|c|c|c|c|c|}
\hline & \multicolumn{2}{|c|}{$\begin{array}{l}\text { Low physical } \\
\text { activity } \\
\text { (IACT) } \\
\text { (n 132) }\end{array}$} & \multicolumn{2}{|c|}{$\begin{array}{c}\text { Moderate and high } \\
\text { physical activity } \\
\text { (hACT) } \\
\text { (n 48) }\end{array}$} & \multicolumn{2}{|c|}{$x^{2}$ test } \\
\hline & $n$ & $\%$ & $n$ & $\%$ & $p$ & $x^{2}$ \\
\hline \multicolumn{7}{|c|}{ Education } \\
\hline Primary & 12 & 8.7 & 2 & 4.2 & \multirow{4}{*}{3.589} & \multirow{4}{*}{30.360} \\
\hline Occupational & 14 & 10.7 & 2 & 4.2 & & \\
\hline Secondary & 96 & 72.8 & 26 & 54.2 & & \\
\hline \begin{tabular}{|l|} 
Higher \\
\end{tabular} & 10 & 7.8 & 18 & 37.5 & & \\
\hline \multicolumn{7}{|c|}{ Marital status } \\
\hline Maid & 0 & 0 & 1 & 2.1 & \multirow{4}{*}{$0.001^{*}$} & \multirow{4}{*}{11.001} \\
\hline Married & 105 & 79.6 & 28 & 58.3 & & \\
\hline Widow & 24 & 18.3 & 13 & 27.1 & & \\
\hline Single & 3 & 2.2 & 6 & 12.5 & & \\
\hline \multicolumn{7}{|c|}{ Family status } \\
\hline \begin{tabular}{|l|} 
Living alone \\
\end{tabular} & 17 & 12.5 & 12 & 25.1 & \multirow{3}{*}{$0.042^{*}$} & \multirow{3}{*}{4.113} \\
\hline Living with the family & 113 & 85.2 & 35 & 72.9 & & \\
\hline Living with the juveniles & 3 & 2.3 & 1 & 2.1 & & \\
\hline
\end{tabular}

* statistically significant differences at $\mathrm{p} \leq 0,05$

The marital status $\left(\chi^{2}=11.001 ; \mathrm{p}<0.05\right)$ and the family status $\left(x^{2}=4.113 ; p<0.05\right)$ turned out to be factor that significantly determined the level of physical activity in the senior female inhabitants of Biała Podlaska. Married were $79.57 \%$ of women with IACT and $58.33 \%$ of women with hACT. Another most numerous group were widows (18.28\% lACT, $27.08 \%$ hACT) as well as divorcees or women in separation $2.15 \%$ lACT, $12.50 \%$ hACT). Only the group with hACT included women who had never been married (maids), but they constituted barely $2.08 \%$ of the women from this group. The above described differences were statistically significant (Tab. 2).

The most numerous group amongst the women compared included female seniors living in households with adults (85.23\% lACT, $72.86 \%$ hACT). The percentage of women living alone reached $12.50 \%$ in the group with lACT and $25.08 \%$ in the group with hACT. Respectively $2.27 \%$ and $2.06 \%$ of the female seniors from the physical activity groups were living with juveniles. All these differences were statistically significant (Tab. 2).

Considering the physical activity of the female seniors in the groups compared, a significantly lower body mass was noted in the women declaring moderate and high physical activity (Tab. 3). The difference in the value of this somatic trait reached $5.94 \mathrm{~kg}$. The significant disproportions in body mass were reflected in the BMI value that was significantly lower (by $1.77 \mathrm{~kg} / \mathrm{m}^{2}$ ) in the physically-active group. Considerable differences were additionally observed in the levels of particular tissue components. Worthy of notice is, however, that those differences were statistically significant only in the case of absolute values. The group with moderate and high physical activity was characterized by lower body adiposity (by $3.14 \mathrm{~kg}$ ), a lower lean body mass (by $1.98 \mathrm{~kg}$ ), and a lower absolute content of water in the body (by $1.57 \mathrm{~L}$ ). In contrast, in the case of percentage values only some tendencies may be pointed out as no significant differences were noted in these values. The women who declared moderate or high physical activity were characterized by a lower percentage of fatty tissue (by 1.23\%) as well as by higher lean body mass (by $1.47 \%$ ) and higher water content in the body (by 1.14\%), (Tab. 3).
Table 3. Statistical characteristics of the surveyed women in groups of physical activity

\begin{tabular}{|l|c|c|c|c|c|}
\hline & \multicolumn{2}{|c|}{$\begin{array}{c}\text { Low physical } \\
\text { activity } \\
\text { (IACT) } \\
\text { (n 132) }\end{array}$} & $\begin{array}{c}\text { Moderate and high } \\
\text { physical activity } \\
\text { (hACT) } \\
\text { (n 48) }\end{array}$ & $\begin{array}{c}\text { Value } \\
\text { of } \\
\text { Student's } \\
\text { t-test }\end{array}$ \\
\cline { 2 - 5 } & x & SD & x & SD & \\
\hline Calendar age [years] & 65.7 & 4.8 & 64.3 & 4.2 & 1.8 \\
\hline Body height [cm] & 159.5 & 6.4 & 159.0 & 5.1 & 0.4 \\
\hline Body mass [kg] & 74.6 & 12.1 & 68.7 & 11.1 & $3.0^{*}$ \\
\hline BMI [kg/m ${ }^{2}$ ] & 28.8 & 4.4 & 27.0 & 4.6 & $10.7^{*}$ \\
\hline Fatty tissue [kg] & 31.0 & 9.5 & 27.9 & 8.8 & $2.0^{*}$ \\
\hline Fatty tissue [\%] & 40.9 & 7.0 & 39.4 & 7.1 & 1.3 \\
\hline Lean body mass [kg] & 43.3 & 4.5 & 41.4 & 3.4 & $2.7^{*}$ \\
\hline Lean body mass [\%] & 59.2 & 6.9 & 60.6 & 7.1 & 1.3 \\
\hline Total water [L] & 34.5 & 3.6 & 32.9 & 2.7 & $2.7^{*}$ \\
\hline Total water [\%] & 47.0 & 5.0 & 48.1 & 5.3 & 1.3 \\
\hline
\end{tabular}

* statistically significant differences at $p \leq 0,05$

Furthermore, differences were observed in the frequency and duration of physical activity undertaken by the surveyed female seniors from Biała Podlaska. In all categories of physical exertion (intensive, moderate, walking), higher mean values were noted in the case of women with moderate and high physical activity. The differences noted between groups were statistically significant $(\mathrm{p}<0.05)$. This was reflected in the mean total energy expenditure, which in the group of women with low activity accounted for barely 236.5 MET, whereas in the case of women with moderate and high activity - for 2255.3 MET. In particular categories of physical exertion, the differences between the analyzed groups of women were statistically significant $(p<0.05)$ (Tab. 4).

Table 4. Average frequency, duration and weekly energy expenditure of physical activities undertaken by the surveyed women

\begin{tabular}{|l|c|c|c|c|c|}
\hline \multirow{7}{*}{ Physical activity } & \multicolumn{2}{c|}{$\begin{array}{c}\text { Low physical } \\
\text { activity } \\
\text { (IACT) } \\
\text { (n 132) }\end{array}$} & $\begin{array}{c}\text { Moderate and high } \\
\text { physical activity } \\
\text { (hACT) } \\
\text { (n 48) }\end{array}$ & $\begin{array}{c}\text { Value } \\
\text { of Student's } \\
\text { t-test }\end{array}$ \\
\cline { 2 - 5 } & $\mathrm{x}$ & SD & $\mathrm{x}$ & SD & \\
\hline Intensive & 0.1 & 0.51 & 0.6 & 0.93 & $4.4^{*}$ \\
\hline Moderate & 2.2 & 1.89 & 3.7 & 2.53 & $4.3^{*}$ \\
\hline Walking & 4.7 & 2.25 & 5.8 & 1.92 & $3.0^{*}$ \\
\hline \multicolumn{7}{|c|}{ Duration [min/week] } \\
\hline Intensive & 1.9 & 8.63 & 24.4 & 45.74 & $5.4^{*}$ \\
\hline Moderate & 7.0 & 35.71 & 72.4 & 59.24 & $9.0^{*}$ \\
\hline Walking & 11.3 & 37.08 & 56.4 & 41.04 & $7.0^{*}$ \\
\hline \multicolumn{7}{|c|}{ Weekly energy expenditure [min/week] } \\
\hline Intensive & 1.7 & 18.5 & 115.1 & 133.4 & $9.6^{*}$ \\
\hline Moderate & 60.2 & 353.6 & 1059.6 & 767.6 & $11.9^{*}$ \\
\hline Walking & 174.6 & 426.5 & 1080.6 & 492.4 & $12.1^{*}$ \\
\hline
\end{tabular}

${ }^{*}$ statistically significant differences at $p \leq 0,05$ 


\section{Discussion}

Literature provides ample reports addressing factors that determine wholesome behaviors of adult persons [13,14,15]. They indicate that we differ in terms of physical capabilities and level of physical activity as influenced by social, biological but also behavioral determinants. Among these, the educational status constitutes a significant factor that determines undertaking physical activity. The higher the level of education, the higher the health awareness, health-promoting lifestyle and more rational eating habits are. It confirms the observations made among older inhabitants of Poznań [16] and Upper Silesia [17]. However, this thesis was not corroborated in our survey, as no significant differences were noted in our case in the educational status between women representing different levels of physical activity.

In contrast, the physical activity was significantly determined by marital and family status of the surveyed female seniors. According to Pettee et al. [18] and Sobal and Hanson [19], married women were significantly more frequently physically active than the unmarried women. Opposite observations were made by Prus and Gee [20]. According to these authors, this dependency is strictly related to the fact that the unmarried persons have no household nor family chores, and therefore may devote more time to, e.g., participation in organized forms of physical activity. The correlation demonstrated in our study between family situation and the level of physical activity may be complex in character. On the one hand, running a household with other family members enforces everyday physical activity. It has been confirmed by results of our study and these made by Chad et al. [21], where a higher level of physical activity was noted in the person living in a household with a spouse, compared to persons living alone. In addition, support of other family members has a positive effect on undertaking different forms of physical activity and on the amount of time spent to these activities [22]. On the other hand, living with a family is often a necessity owing to impaired functional and locomotive fitness. This may result in the loss of self-dependence and the necessity of remaining under the care of other persons.

Systematic physical activity retards involution processes, lowers the risk of civilization diseases and contributes to good well-being. It additionally affects the quality of man's life [23]. Results obtained in our study demonstrate significant differences in the body mass of the surveyed female seniors depending on their physical activity. A significantly lower level of this somatic trait in the women who declared moderate or high level of physical activity influenced also lower BMI values in this group. Such a correlation has already been confirmed in a research by Sternfeld et al. [24], who emphasize the key significance of regular physical activity in maintaining body mass at a stable level. What is more, Ekezie et al. [25] show that everyday exercises with low and medium intensity may exert a positive effect on BMI changes and that continued physical activity may contribute to the improvement of cognitive functions [26] as well as physical and locomotive fitness [27]. Unfortunately, the number of persons continuing systematic exercises is decreasing with age. It is worth emphasizing, however, that even if women spent a significant part of the day on everyday chores, too little intensity of these activities and consequently too low consumption of energy provided with food diminish their effect on reduction or maintenance of a stable body mass.

There is no explicit data on what type of undertaken physical activity is the most effective. The positive impact of regular physical exercises on body composition in the post-menopausal period in women was described, among others, by Sims et al. [28]. In turn, Chubak et al. [29] noticed that aerobic exercises with moderate intensity had no effect on contents of particular tissue components in post-menopausal women. In a survey conducted with women at the age of 65-72, Traaffe et al. [30] proved that differences in body composition of female seniors could be observed already when the group declaring to be physically-active underwent a special strength training. Furthermore, Genton et al. [31] prove that energy expenditure caused by undertaking physical activity substantially reduces the loss of lean body mass. Moreover, persons with a higher physical activity are less exposed to motion impairments than those with excessive body mass who lead a sedentary lifestyle [32,33]. Although Rolland et al. [34] claim that the loss of muscle tissue does not necessarily have to be linked with functional impairments. However, most researchers, e.g. Brach et al. [35], prove that older persons who perform 20-30-min exercises of moderate intensity in most days of the week show a significantly better physical fitness.

\section{Conclusions}

In the surveyed population of older female inhabitants of Biała Podlaska the marital status and the family status were modifying the level of physical activity to a greater extent than the educational status did. In addition, significant correlations were demonstrated between absolute values of tissue components of the body and the physical activity of the female seniors. On contrast, moderate and high physical activity differentiated to a low extent the body composition of the women expressed in per cents. The differences noted enable concluding that not only time devoted to physical activity but also its intensity affected the levels of tissue components. Results achieved in the survey point to the necessity of continuing studies in terms of correlations between body composition and physical activity of older people considering their nutritional habits.

\section{Acknowledgments}

The research was accomplished within the framework of statutory research of Faculty of Physical Education and Sport in Biała Podlaska, the Josef Pilsudski University of Physical Education in Warsaw - DS. 124 - financed by the Ministry of Science and Higher Education.

\section{Literature}

1. WHO. (2007). Definition of an Older or Elderly Person. Retrieved October 1 2012, from WHO database on the World Wide Web: http://www.who.int/healthinfo/survey/ageingdefnolder/en/index.html.

2. Li Z., Heber D. (2012). Sarcopenic obesity in the elderly and strategies for weight management. Nutrition Reviews 70(1), 57-64. DOI: 10.1111/j.1753-4887.2011.00453.x.

3. Kragstrup T.W., Kjaer M., Mackey A.L. (2011). Structural, biochemical, cellular, and functional changes in skeletal muscle extracellular matrix with aging. Scandinavian Journal of Medicine \& Science in Sports 21(6), 749-757. DOI: 10.1111/j.1600-0838.2011.01377.x.

4. Green J.O., Nagaraja S., Tamim D.T., Vidakovic B., Guldberg R.E. (2011). Age-related changes in human trabecular bone: Relationship between microstructural stress and strain and damage morphology. Journal of Biomechanics 44(12), 22792285. DOI: org/10.1016/j.jbiomech.2011.08.006.

5. Jones T.E., Stephenson K.W., King J.G., Knight K.R., Marshall T.L., Scott W.B. (2009). Sarcopenia - mechanisms and treatments. The Journal of Geriatric Physical Therapy 32(3), 110. 
6. Shepard R.J. (2009). Maximal oxygen intake and independence in old age. British Journal of Sports Medicine 43, 342346. DOI:10.1136/bjsm.2007.044800.

7. Chodźko-Zajko W.J., Proctor D.N., Fiatarone Singh M.A., Minson C.T., Nigg C.R., Salem G.J. et al. (2009). American College of Sports Medicine position stand. Exercise and physical activity for older adults. Medicine $\mathcal{\sigma}$ Science in Sports \& Exercise 41(7), 1510-1530. DOI: 10.1249/MSS.0b01 3e3181a0c95c.

8. Ignasiak Z., Skrzek A., Dąbrowska G. (2009). Bone mineral density and body composition of senior female students of the University of the Third Age in view of their diverse physical activity. Human Movement 10(2), 109-115. DOI:10. 2478/v10038-009-0015-1

9. WHO. (2000). Obesity: preventing and managing the global epidemic. Report of a WHO Consultation. WHO Technical Report Series 894. Geneva: World Health Organization. Retrieved October 12012 , from WHO database on the World Wide Web: https://apps.who.int/nut/documents/obesity_executive summary.pdf

10. Dehghan M., Merchant A.T. (2008). Is bioelectrical impedance accurate for use in large epidemiological studies? Nutrition Journal 9(7), 26. DOI:10.1186/1475-2891-7-26.

11. Biernat E., Stupnicki R., Gajewski A.K. (2007). International Physical Activity Questionnaire (IPAQ) - polish version. Wychowanie Fizyczne i Sport 51, 47-54. [in Polish]

12. Główny Urząd Statystyczny. (2011). The health status of Polish population in 2009. Warszawa: Główny Urząd Statystyczny. Informacje i Opracowania. [in Polish]

13. Prus S.G., Gee E. (2003). Gender differences in the influence of economic, lifestyle, and psychosocial factors on later-life health. The Canadian Journal of Public Health 94(4), 306309.

14. Katzmarzyk P. (2007). Physical activity and fitness with age among sex and ethnic group. In C. Bouchard, S.N. Blair, W. Haskell (Eds.) Physical activity and health. Champaign: Human Kinetics.

15. Hawkins S., Cockburn M., Hamilton A., Mack T. (2004). An estimate of physical activity prevalence in a large population - based cohort. Medicine $\&$ Science in Sports \& Exercise 36(2), 253-260.

16. Szeklicki R. (2006). Level of education, material status and social contacts as determinants of habitual physical activity among elderly men. Studies in Physical Culture and Tourism 13, 93-97.

17. Knapik A., Rottermund J., Myśliwiec A., Plinta R., Gruca M. (2011). Physical activity and health self-assessment of the elderly. Przegląd Medyczny Uniwersytetu Rzeszowskiego i Narodowego Instytutu Leków w Warszawie 2, 195-204. [in Polish]

18. Pettee K.K., Brach J.S., Kriska A.M., Boudreau R., Richardson C.R., Colbert L.H. et al. (2006). Influence of marital status on physical activity levels among older adults. Medicine \& Science in Sports \& Exercise 38(3), 541-546.

19. Sobal J., Hanson K. (2010). Marital status and physical activity in U.S. adults. The International Journal of Sociology of the Family 36(2), 181.

20. Prus S.G., Gee E. (2003). Gender differences in the influence of economic, lifestyle, and psychosocial factors on later-life health. The Canadian Journal of Public Health 94(4), 306-309.

21. Chad K.E., Reeder B.A., Harrison E.L., Ashworth N.L., Sheppard S.M., Schultz S.L. et al. (2005). Profile of physical activity levels in community-dwelling older adults. Medicine \& Science in Sports \& Exercise 37(10), 1774-1784.

22. Deforche B., De Bourdeaudhuij I. (2000). Differences in psychosocial determinants of physical activity in older adults participating in organized versus non-organized activities. The Journal of Sports Medicine and Physical Fitness 40(4), 362-372.
23. Duda B. (2008). Physical activity and fitness of adults aged 60-69 years. The Polish Journal of Sports Medicine 24(6), 379-384.

24. Sternfeld B., Wang H., Quesenberry C.P. Jr, Abrams B., Everson-Rose S.A., Greendale G.A. et al. (2004). Physical activity and changes in weight and waist circumference in midlife women: findings from the Study of Women's Health Across the Nation. American Journal of Epidemiology 160(9), 912-922. DOI:10.1093/aje/kwh299.

25. Ekezie J., Adebisi S., Danborno B. (2009). The effect of marital status and self-reported physical exercise on the adiposity and blood pressure of the Igbos of Nigeria. Journal of Medical Update 4(1), 7-14.

26. Weuve J., Kang J., Manson J., Breteler M., Ware J., Grodstein F. (2004). Physical activity, including walking, and cognitive function in older women. Journal of the American Medical Association 292(12), 1454-1561.

27. Jachimowicz V., Kostka T. (2009). Association between physical activity and functional and motor abilities among the elderly. The Polish Journal of Sports Medicine 4(6), 256-264. [in Polish]

28. Sims S.T., Larson J.C., Lamonte M.J., Michael Y.L., Martin L.W., Johnson K.C. et al. (2012). Physical activity and body mass: changes in younger versus older postmenopausal women. Medicine \& Science in Sports \& Exercise 44(1), 8997. DOI:10.1249/MSS.0b013e318227f906.

29. Chubak J., Ulrich C.M., Tworoger S.S., Sorensen B., Yasui Y. Irwin M.L. et al. (2006). Effect of exercise on bone mineral density and lean mass in postmenopausal women. Medicine \& Science in Sports \& Exercise 38(7), 1236-1244. DOI: 10. 1249/01.mss.0000227308.11278.d7.

30. Taaffe D.R., Pruitt L., Pyka G., Guido D., Marcus R. (1996). Comparative effects of high-and low-intensity resistance training on thigh muscle strength, fiber area, and tissue composition in elderly women. Clinical Physiology 16(4), 381-392.

31. Genton L., Karsegard V., Chevalley T., Kossovsky M., Darmon P., Pichard C. (2011). Body composition changes over 9 years in healthy elderly subjects and impact of physical activity. Clinical Nutrition 30(4), 436-442. DOI:10.1016/j. clnu.2011.01.009.

32. Seguin R., Lamonte M., Tinker L., Liu J., Woods N., Michael Y. et al. (2012). Sedentary behavior and physical function decline in older women: findings from the Women's Health Initiative. Journal of Aging Research 60, 719-725. DOI: 10. 1111/j.1532-5415.2012.03906.x

33. Yorston L., Kolt G., Rosenkranz R. (2012). Physical activity and physical function in older adults: the 45 and up study. Journal of the American Geriatrics Society 60(4), 719-725. DOI: 10.1111/j.1532-5415.2012.03906.x

34. Rolland Y., Lauwers-Cances V., Cristini C., Abellan van Kan G., Janssen I., Morley J. et al. (2009). Difficulties with physical function associated with obesity, sarcopenia, and sarcopenic-obesity in community-dwelling elderly women: the EPIDOS (EPIDemiologie de l'OSteoporose) Study. The American Journal of Clinical Nutrition 89(6), 1895-1900. DOI: 10. 3945/ajcn.2008.26950.

35. Brach J., Simonsick E., Kritchevsky S., Yaffe K., Newman A. (2004). Health, aging and body composition study research group. The association between physical function and lifestyle activity and exercise in the health, aging and body composition study. Journal of the American Geriatrics Society 52(4), 502-509.

Submitted: October 22, 2012

Accepted: January 9, 2013 